Article

\title{
Synthesis and Characterization of Mechanical Properties and Wire Cut EDM Process Parameters Analysis in AZ61 Magnesium Alloy $+\mathrm{B}_{4} \mathrm{C}+\mathrm{SiC}$
}

\author{
Thanikodi Sathish ${ }^{1, *}$, Vinayagam Mohanavel ${ }^{2}$, Khalid Ansari ${ }^{3} \mathbb{D}$, Rathinasamy Saravanan ${ }^{1}$ (D), \\ Alagar Karthick ${ }^{4}\left(\mathbb{D}\right.$, Asif Afzal ${ }^{5, *(D)}$, Sagr Alamri ${ }^{6,7}$ and C. Ahamed Saleel ${ }^{6}$ (D)
}

1 Department of Mechanical Engineering, Saveetha School of Engineering, Saveetha Institute of Medical and Technical Sciences (SIMATS), Chennai 602105, India; r.sarravanan@gmail.com

2 Centre for Materials Engineering and Regenerative Medicine, Bharath Institute of Higher Education and Research, Chennai 600073, India; mohanavel2k16@gmail.com

3 Department of Civil Engineering, Yeshwantrao Chavan College of Engineering, Nagpur 441110, India; khalidshamim86@rediffmail.com

4 Department of Electrical and Electronics Engineering, KPR Institute of Engineering and Technology, Coimbatore 641407, India; karthick.power@gmail.com

5 Department of Mechanical Engineering, P. A. College of Engineering, Visvesvaraya Technological University, Mangaluru 574153, India

6 Mechanical Engineering Department, College of Engineering, King Khalid University, P.O. Box 394, Abha 61421, Saudi Arabia; salamri@kku.edu.sa (S.A.); ahamedsaleel@gmail.com (C.A.S.)

check for updates

Citation: Sathish, T.; Mohanavel, V.; Ansari, K.; Saravanan, R.; Karthick,

A.; Afzal, A.; Alamri, S.; Saleel, C.A. Synthesis and Characterization of Mechanical Properties and Wire Cut EDM Process Parameters Analysis in AZ61 Magnesium Alloy $+\mathrm{B}_{4} \mathrm{C}+\mathrm{SiC}$. Materials 2021, 14, 3689. https:// doi.org/10.3390/ma14133689

Academic Editors: Bryan M. Wong and Young-Hag Koh

Received: 4 May 2021

Accepted: 25 June 2021

Published: 1 July 2021

Publisher's Note: MDPI stays neutra with regard to jurisdictional claims in published maps and institutional affiliations.

Copyright: (c) 2021 by the authors. Licensee MDPI, Basel, Switzerland. This article is an open access article distributed under the terms and conditions of the Creative Commons Attribution (CC BY) license (https:// creativecommons.org/licenses/by/ $4.0 /)$.
7 Department of Mechanical Engineering, The University of Akron, Akron, OH 44325-3903, USA

* Correspondence: sathish.sailer@gmail.com (T.S.); asif.afzal86@gmail.com (A.A.)

\begin{abstract}
Wire Cut Electric Discharge Machining (WCEDM) is a novel method for machining different materials with application of electrical energy by the movement of wire electrode. For this work, an AZ61 magnesium alloy with reinforcement of boron carbide and silicon carbide in different percentage levels was used and a plate was formed through stir casting technique. The process parameters of the stir casting process are namely reinforcement \%, stirring speed, time of stirring, and process temperature. The specimens were removed from the casted AZ61 magnesium alloy composites through the Wire Cut Electric Discharge Machining (WCEDM) process, the material removal rate and surface roughness vales were carried out creatively. L 16 orthogonal array (OA) was used for this work to find the material removal rate (MRR) and surface roughness. The process parameters of WCEDM are pulse on time $(105,110,115$ and $120 \mu \mathrm{s})$, pulse off time $(40,50,60$ and $70 \mu \mathrm{s})$, wire feed rate $(2,4,6$ and $8 \mathrm{~m} / \mathrm{min})$, and current $(3,6,9$ and 12 Amps). Further, this study aimed to estimate the maximum ultimate tensile strength and micro hardness of the reinforced composites using the Taguchi route.
\end{abstract}

Keywords: wire cut electrical discharge machining; tensile strength; wire feed rate; AZ61; surface roughness; material removal rate (MRR)

\section{Introduction}

Manufacturing units need more effective materials to produce novel components for suitable application; this need is satisfied by preparing two or more materials in the composite nature. These composites are mainly used as hopeful materials, the metal matrix composites (MMCs) functionally used to improve the more strength and good wear characteristics. The investigation made on the AZ61 magnesium alloys with reinforced alumina $\left(\mathrm{Al}_{2} \mathrm{O}_{3}\right)$ by $2 \mathrm{wt} \%$ and silicon carbide $(\mathrm{SiC})$ of $0.5,1,1.5 \mathrm{wt} \%$ nanoparticle hybrid. The excellent hardness, tensile and compressive strength of the composites are concerned with a direct correlation with the reinforcement of $\mathrm{SiC}$ filling, the maximum values are found by the addition of $1 \mathrm{wt} \%$ of $\mathrm{SiC}$ along with $\mathrm{AZ} 61+2 \mathrm{wt} \% \mathrm{Al}_{2} \mathrm{O}_{3}$ hybrid composite [1]. 
The Wire Electrical Discharge Machining process of Shape Memory Alloys surface analysis was carried out [2]. For their investigations the results designate that, for the duration of WCEDM (Wire Cut Electrical Discharge Machining) of nitinol Shape Memory Alloys (SMA), proper discharge power is required to accomplish the optimal surface roughness. The compression test considering the material of ZK60 magnesium alloy with different temperature ranges such as $200-400{ }^{\circ} \mathrm{C}$, also considering the strain range of 0.001-1 s ${ }^{-1}$ was conducted [3] For their result, ZK60 magnesium alloy flow stress can be decreased by increasing deformation temperature as well as reduction of strain rate. Using of nano-sized particles can increase the strength of the metal matrix and also sustain the ductility of the aluminum matrix alloy [4]. The authors considered micro level of silicon carbide and nano level of copper oxide with different weight percentages. The base material and reinforced particles were pressed by cold compacting method and finally the green compacts were sintered. They found the excellent tensile strength and micro hardness of the sintered composites; further, they revealed the microstructure by use of scanning electron microscope (SEM).

Magnesium matrix composites with use of silicon carbide reinforced particles are carried out by stir casting process [5]. They used different particles in size levels such as micron level, submicron level and nano level. For their investigation, they chose the stir casting process and extrusion process to improve the magnesium composite strength. They found that the accumulation of different sizes of $\mathrm{SiC}$ particles directly improve the ratio of DRXed nucleation. Similarly it can reduce the typical particle size of the matrix. The tensile strength of the composites also improved compared to without addition of $\mathrm{SiC}$ material.

The Mechanical Properties are improved in the aluminum alloy with addition of nano $\mathrm{B}_{4} \mathrm{C}$ nano composites by the way of stir casting process [6]. In the microstructure analysis, the boron carbide nano particles disseminated to the aluminum alloy with excellent condition were identified. Increasing of nano boron carbide particles extensively increased the mechanical properties such as tensile strength and hardness. They revealed that the result of dry sliding wear resistance of the nano $\mathrm{B}_{4} \mathrm{C}$ composites was higher than monolithic aluminum alloys.

Machining process of magnesium ZC63 alloy with reinforced silicon carbide by use of wire cut EDM process was conducted [7]. The authors considered different parameters to conduct the wire cut EDM. For their result, increasing of the pulse-on time and wire tension parameters increased the material removal rate. On the contrary, the surface roughness was reduced. Analyzing the machining parameters of wire cut EDM process for SKD11 material is one of the critical one due to its hardness level [8]. Surface roughness was modified by the influence of pulse on time and pulse off time parameters. In the material removal rate (MRR) analysis, the wire speed parameter was highly influenced. MRR was increased by increasing of pulse on time and wire speed. In contrast, the surface roughness was decreased. In both approaches such as BPNN-GA and RSM, the BPNN-GA provides precise output results compared to response surface methodology (RSM) approach. The back propagation neural network combining with genetic algorithm methodology predicted the values in perfect mode.

The liquid phase materials offer good mixing of constituent elements achieved by stir casting process by means of stirring nature. The liquid molten state material is finally casted by the required shape with any size. In the stir casting process, the stirring speed plays a major role to mix the elements or reinforced particles to give excellent mechanical strength after casted components. The stirring time is also important for the particular time taken to distribute particles uniformly [9]. For pouring the liquid into the mold, the pouring rate influences the decision of the quality of the casting and also introduces the possibility to form defects [10-13].

In the wire cut EDM machining process, thin metallic wire is fed into the specimens constantly which is surrounded by passing of dielectric fluid. The continual feed of the wire is controlled by the guides placed on upper and lower positions to give the uniform speed and tempering nature [14,15]. In the WCEDM, the wires are generally made up of 
brass materials. The WCEDM is a thermo-electrical approach of cutting the samples at any profiles easily; the erosion action can be completed between samples and electrodes with introduction of an electrical spark [16-19]. The circulated water improves the feed rate of the wires by removal or washes out the debris from the machining zone.

In the wire cut EDM process, the current passes on the wire on one side and on the other end the specimen carrying the current. The wire moves close to the specimen at the time the pulling of electrical charges is introduced; it causes the melting and vaporization in the specimens to cut any profile [20-24]. The MRR and surface roughness analysis is important in the machining process as the tool performance, machine performance as well as parameter involvement have to be measured. In general, the MRR can be calculated by use of removed material weight such as before machining and after machining the weight of the component has to be estimated [25-28]. Surface roughness is one of the desirable factors for matting or aligning two surfaces without any trouble in the assembly line in the industries [29].

Surface roughness was measured by applying a surface roughness tester in a short time period; it can be varied by the influence of machine vibration, type of tool and material and coolant supply [30]. The limitations of the stir casting process are the conclusion of reinforcement material melting temperature which is renowned as three times that of base metal. Further, it is reported that the agglomeration of reinforcement particles in the molten material is an extremely crucial aspect in the surface finish and crack propagation. All research work focused on analysis of the mechanical properties, especially the tensile strength and micro hardness. Based on the literature study the AZ61 magnesium alloy is chosen for this work, the selected material is stir casted with reinforced of boron carbide and silicon carbide, finally the small size of specimens is cut by use of wire cut EDM [31]. After the wire cut the material removal rate and surface roughness is analyzed for the effect of wire cut process parameters [32]. Further, the mechanical strength such as tensile strength and micro hardness were tested.

\section{Materials and Methods}

The magnesium alloy AZ61 (Parshwamani Metals, Mumbai, Maharashtra, India) has excellent machinability character, lightweight material and also easy casting for any form. This alloy offered good corrosion resistance in all environmental conditions [33]. The contribution of elements in weight percentage is presented in the Table 1. The highest ultimate strength is offered by the AZ61 magnesium alloy, the remarkable mechanical properties such as hardness, shear strength, compressive strength, bearing strength and impact strength are listed in the Table 2.

Table 1. Chemical composition of AZ61 magnesium alloy.

\begin{tabular}{cc}
\hline Material & \% of Composition \\
\hline Aluminum Al & 6.510 \\
Zinc Zn & 1.092 \\
Iron Fe & 0.004 \\
Nickel Ni & 0.001 \\
Manganese Mn & 0.220 \\
Silicon Si & 0.040 \\
Copper Cu & 0.003 \\
Magnesium Mg & 92.13 \\
\hline
\end{tabular}


Table 2. Mechanical properties of AZ61 magnesium alloy.

\begin{tabular}{cc}
\hline Properties & Metric MPa \\
\hline Tensile strength & 310 \\
Yield strength & 230 \\
Compressive yield strength & 130 \\
Ultimate bearing strength & 470 \\
Bearing yield strength & 285 \\
Shear strength & 140 \\
Elongation at break & $16 \%$ \\
\hline
\end{tabular}

\section{Experimental Procedure}

This work was divided into two categories: first the material removal rate and surface roughness analysis was conducted by using L16 orthogonal array $(\mathrm{OA})$ with optimization of wire cut EDM process parameters [34]. Further, the tensile strength and micro hardness were evaluated by optimization of stir casting process parameters. Stir casting process is a novel method to achieve homogeneous mixture of the hybrid composites with effective strength. The hard particles of the boron carbide and silicon carbide particles (Bhukhanvala, Mumbai, Maharashtra, India) were weighed separately, and the reinforcement percentage was considered uniformly such as $8 \%$. AZ61 magnesium alloy of powder form was weighed at the required level in the digital balance (Prolab, Mumbai, Maharashtra, India). Initially the magnesium alloy was melted in the furnace (Vibrant Thermal Engineering, Chennai, Tamil Nadu, India) with elevated temperature, at the time of melting condition the reinforced particles of boron carbide and silicon carbide were put in the furnace and the temperature was maintained around $800^{\circ} \mathrm{C}$. The agitation process enhanced the properties of the hybrid composites as well as increased the strength [35]. The stirring speed of this investigation varied such as 450,500, 550 and $600 \mathrm{rpm}$ with varying time of stirring such as 15, 20, 25 and $30 \mathrm{~min}$. The pure molten state of the Mg AZ61 was poured in the mold cavity of rectangular shape for the dimension of $200 \times 100 \times 15 \mathrm{~mm}^{3}$, as shown in Figure 1 .

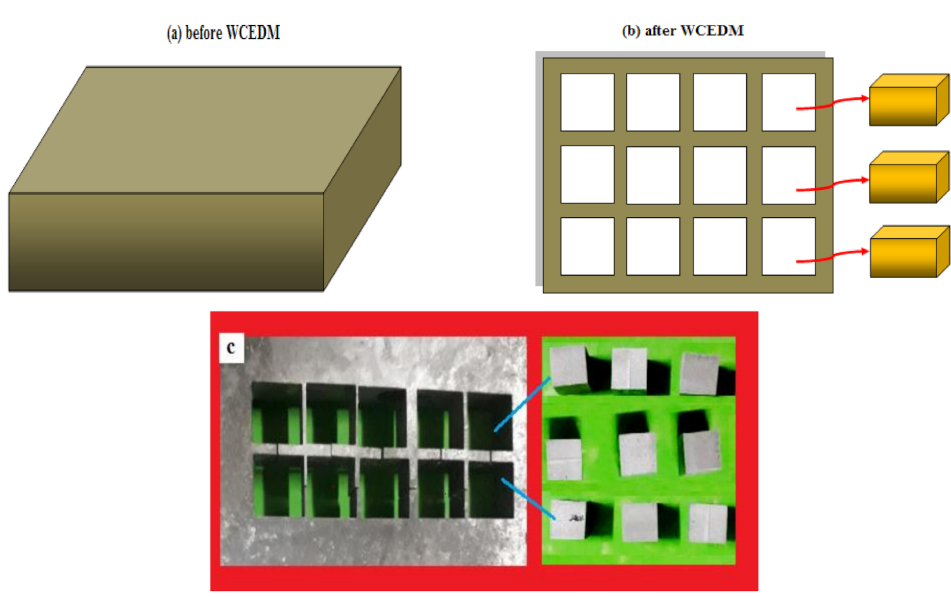

Figure 1. Schematic view of (a) casted AZ61Mg specimen (b) after WCEDM (Wire Cut Electrical Discharge Machining) specimen and (c) casted raw material with machined specimens.

The stir casted part was further machined by use of wire cut EDM with selected different cutting factors such as pulse on time $(105,110,115$ and $120 \mu \mathrm{s})$, pulse off time (40, $50,60$ and $70 \mu \mathrm{s})$, wire feed rate $(2,4,6$ and $8 \mathrm{~m} / \mathrm{min})$, and current $(3,6,9$ and $12 \mathrm{Amps})$. The debris was flushed by use of circulated ionized water into the cutting area improving the cutting action [36-38]. Before cutting and after cutting the material was weighed to calculate the MRR of each specimen [39]. 


\subsection{Wire Cut EDM Process}

The CNC (Computer Numerical Control) Wire EDM Machine (Model: AW6S, Electronica, Kolkata, India) was used to machine the stir casted specimens. Wire tension of the machine was 200-2500 gf, machine operated power supply as $5400+350 \mathrm{~kg}$ and the movement of the $X$ direction and $Y$ direction distance was 650 and $450 \mathrm{~mm}$, respectively.

Reinforcements of boron carbide and silicon carbide to the AZ61 Mg alloy were highly influenced in the WEDM process. In this investigation it was found that larger reinforced particles considerably reduced the material removal rate, compared to small sized particles it can highly protect the matrix material from EDM sparks. The WEDM process was carried out in the Motto Machining solutions, Coimbatore.

The four process parameters namely pulse on time, pulse off time, wire feed rate and current of the wire cut electric discharge machining process and their chosen values are presented in Table 3. These parameters are highly involved in the wire cut EDM process to improve the MRR and also reduce the surface roughness [40].

Table 3. WCEDM process parameters.

\begin{tabular}{cc}
\hline Parameters & Values \\
\hline Pulse on time $(\mu \mathrm{s})$ & $105,110,115$ and 120 \\
Pulse off time $(\mu \mathrm{s})$ & $40,50,60$ and 70 \\
Wire feed rate $(\mathrm{m} / \mathrm{min})$ & $2,4,6$ and 8 \\
Current $(\mathrm{Amps})$ & $3,6,9$ and 12 \\
\hline
\end{tabular}

\subsection{Surface Roughness Analysis}

The surface roughness was measured by use of Mitutoyo surface roughness testing machine (India Tools and Instruments, Mumbai, India) effectively as shown in Figure 2. Aerospace model Vernier height gauge was used to clamp the surface roughness tester unit; further, the V-block and C-Clamp were used to hold the specimen in the correct position level. All the samples were measured by this instrument to obtain precision results.

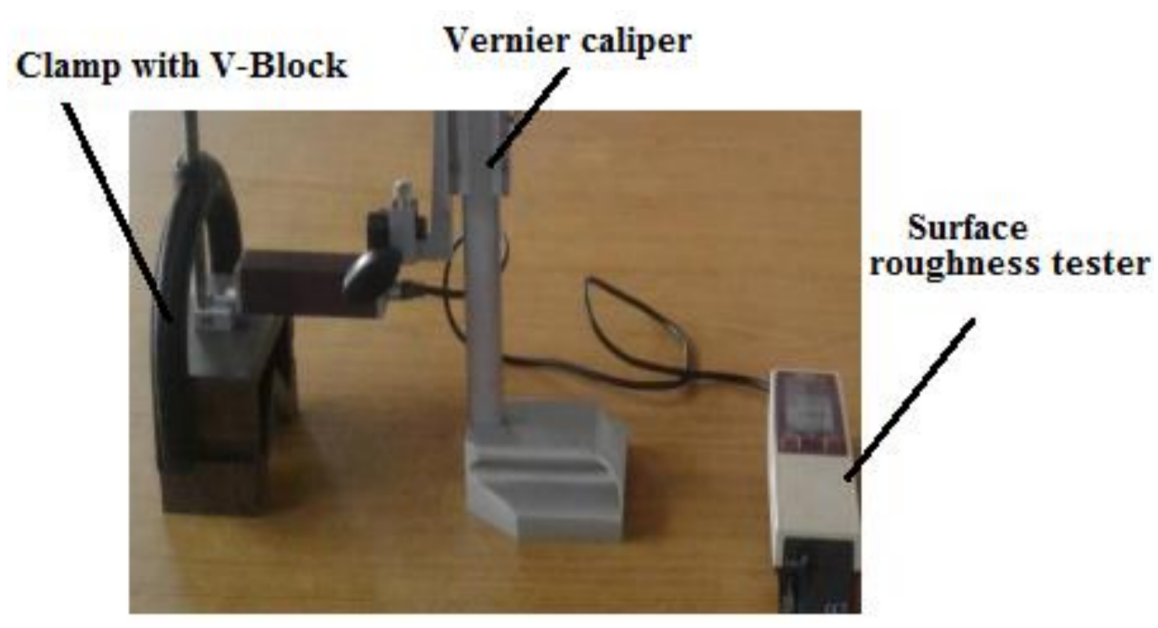

Figure 2. Mitutoyo hardness tester.

\subsection{Tensile Strength Analysis}

Stir casted $\mathrm{AZ} 61+\mathrm{B}_{4} \mathrm{C}+\mathrm{SiC}$ hybrid composite specimens were tested in the tensile testing machine (Model: ZY 2075-A series, (Blue star Engineering and Electronics, Mumbai, India), maximum of $100 \mathrm{kN}$ capacity and pneumatically operated jaws). The parameters that were selected for the tensile test are reinforcement $\%$, stirring speed, time of stirring, and process temperature as presented in Table 4 . 
Table 4. Stir casting process parameters.

\begin{tabular}{cc}
\hline Parameters & Values \\
\hline Reinforcement $(\%)$ & $2,4,6$ and 8 \\
Stirring speed (rpm) & $450,500,550$ and 600 \\
Time of stirring $(\mathrm{min})$ & $15,20,25$ and 30 \\
Process temperature $\left({ }^{\circ} \mathrm{C}\right)$ & $650,700,750$ and 800 \\
\hline
\end{tabular}

\subsection{Micro Hardness Analysis}

Hardness is one of the major mechanical properties of the materials in engineering application [41]. The micro hardness is the precision measurement of the hardness with the help of Vickers hardness tester (YESAAR TECH, Chennai, India), measuring range: 5-300 HV, for the testing force are 10, 25, 50, 100, 200, 300, 500, $100 \mathrm{gf}$; magnification of the testing: $500 \times, 125 \times$; lowest measurement of microscope: $0.025 \mu \mathrm{m}$ ). All the 16 samples were tested with the effects of stir casting parameters.

\section{Result and Discussion}

\subsection{Material Removal Rate (MRR)}

The wire cut EDM was carried out by influence of the elected parameters effectively, the parameters of pulse on time $(\mu \mathrm{s})$, pulse off time $(\mu \mathrm{s})$, wire feed rate $(\mathrm{m} / \mathrm{min})$ and current (Amps). All the parameters and the output result of material removal rate are summarized and tabulated in Table 5. From the table, maximum material removal rate was obtained as $0.212 \mathrm{~mm}^{3} / \mathrm{s}$. Table 6 presents the response table for signal to noise ratios of material removal rate. From this table, the wire feed rate parameter has the highest influencing factor in MRR, continually the pulse on time, pulse off time and current. The optimal parameters were recorded as $115 \mu$ s of pulse on time, $50 \mu$ s of pulse off time, $3 \mathrm{~m} / \mathrm{min}$ of wire feed rate and 6 Amps of current.

Table 5. Summary of WCEDM and material removal rate (MRR) results.

\begin{tabular}{|c|c|c|c|c|c|}
\hline Exp. No & Pulse on Time $(\mu s)$ & Pulse off Time $(\mu \mathrm{s})$ & Wire Feed Rate (m/min) & Current (Amps) & $\begin{array}{l}\text { Material Removal Rate } \\
\text { (MRR) }\left(\mathrm{mm}^{3} / \mathrm{s}\right)\end{array}$ \\
\hline 1 & 105 & 40 & 2 & 3 & 0.069 \\
\hline 2 & 105 & 50 & 4 & 6 & 0.175 \\
\hline 3 & 105 & 60 & 6 & 9 & 0.077 \\
\hline 4 & 105 & 70 & 8 & 12 & 0.162 \\
\hline 5 & 110 & 40 & 4 & 9 & 0.189 \\
\hline 6 & 110 & 50 & 2 & 12 & 0.083 \\
\hline 7 & 110 & 60 & 8 & 3 & 0.202 \\
\hline 8 & 110 & 70 & 6 & 6 & 0.097 \\
\hline 9 & 115 & 40 & 6 & 12 & 0.173 \\
\hline 10 & 115 & 50 & 8 & 9 & 0.212 \\
\hline 11 & 115 & 60 & 2 & 6 & 0.144 \\
\hline 12 & 115 & 70 & 4 & 3 & 0.192 \\
\hline 13 & 120 & 40 & 8 & 6 & 0.092 \\
\hline 14 & 120 & 50 & 6 & 3 & 0.167 \\
\hline 15 & 120 & 60 & 4 & 12 & 0.142 \\
\hline 16 & 120 & 70 & 2 & 9 & 0.135 \\
\hline
\end{tabular}

Table 6. Response table for signal to noise ratios (material removal rate).

\begin{tabular}{ccccc}
\hline Level & $\begin{array}{c}\text { Pulse on Time } \\
(\boldsymbol{\mu} \mathbf{s})\end{array}$ & $\begin{array}{c}\text { Pulse off Time } \\
(\boldsymbol{\mu} \mathbf{s})\end{array}$ & $\begin{array}{c}\text { Wire Feed Rate } \\
(\mathbf{m} / \mathbf{m i n})\end{array}$ & $\begin{array}{c}\text { Current } \\
(\text { Amps })\end{array}$ \\
\hline 1 & -19.11 & -18.41 & -19.77 & -16.75 \\
2 & -17.56 & -16.44 & -15.22 & -18.24 \\
3 & -14.97 & -17.49 & -18.33 & -16.90 \\
4 & -17.65 & -16.95 & -15.98 & -17.41 \\
Delta & 4.14 & 1.97 & 4.54 & 1.49 \\
Rank & 2 & 3 & 1 & 4 \\
\hline
\end{tabular}


In Figure 3, the Pareto chart of material removal rate by wire feed rate is illustrated effectively by the contribution of wire feed rate. The $80 / 20$ rule was implemented for this experiment, influencing the wire feed rate of $2 \mathrm{~m} / \mathrm{min}$ the minimum MRR was obtained as $0.069 \mathrm{~mm}^{3} / \mathrm{s}$ and $4 \mathrm{~m} / \mathrm{min}$ of wire feed produced the $0.142 \mathrm{~mm}^{3} / \mathrm{s}$ of MRR. Increasing the wire feed rate of $6 \mathrm{~m} / \mathrm{min}$ obtained an MRR of $0.077 \mathrm{~mm}^{3} / \mathrm{s}$. Finally for the $8 \mathrm{~m} / \mathrm{min}$ wire feed rate the obtained MRR was $0.092 \mathrm{~mm}^{3} / \mathrm{s}$. All these values are minimum and better for changing the parameters. Figure 4 shows the Pareto chart of material removal rate by influencing pulse on time. Application of minimum pulse on time $105 \mu$ s obtained MRRs of 0.069 and $0.077 \mathrm{~mm}^{3} / \mathrm{s}$. By slightly increasing the pulse on time to $110 \mu \mathrm{s}$, the MRR was obtained as 0.083 and $0.097 \mathrm{~mm}^{3} / \mathrm{s}$. Using $115 \mu$ s of pulse on time, the material removal rate was found as $0.142 \mathrm{~mm}^{3} / \mathrm{s}$. Finally, using $120 \mu$ s of pulse on time attained an MRR of $0.092 \mathrm{~mm}^{3} / \mathrm{s}$. Maximum MRR $\left(0.142 \mathrm{~mm}^{3} / \mathrm{s}\right)$ can be achieved by using $115 \mu$ s of pulse on time.

\section{Pareto Chart of MRR $\left(\mathrm{mm}^{3} / \mathrm{s}\right)$ by Wire feed $(\mathrm{m} / \mathrm{min})$}

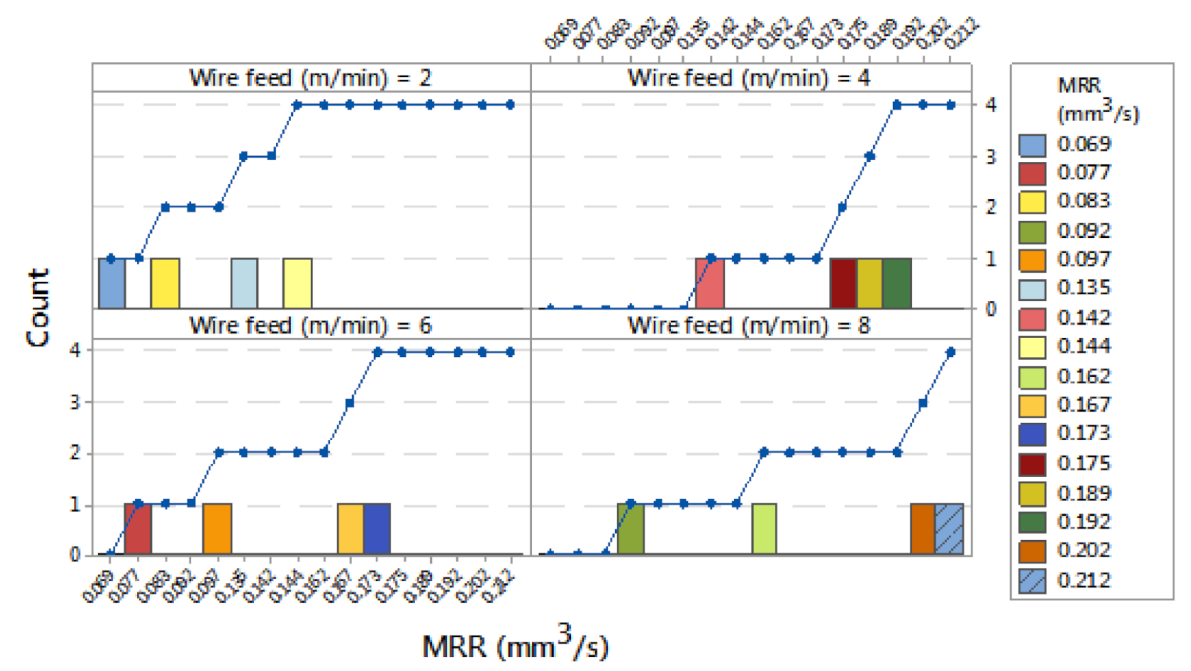

Figure 3. Pareto chart of material removal rate by wire feed rate.

\section{Pareto Chart of MRR $\left(\mathrm{mm}^{3} / \mathrm{s}\right)$ by Pulse on time $(\mu \mathrm{s})$}

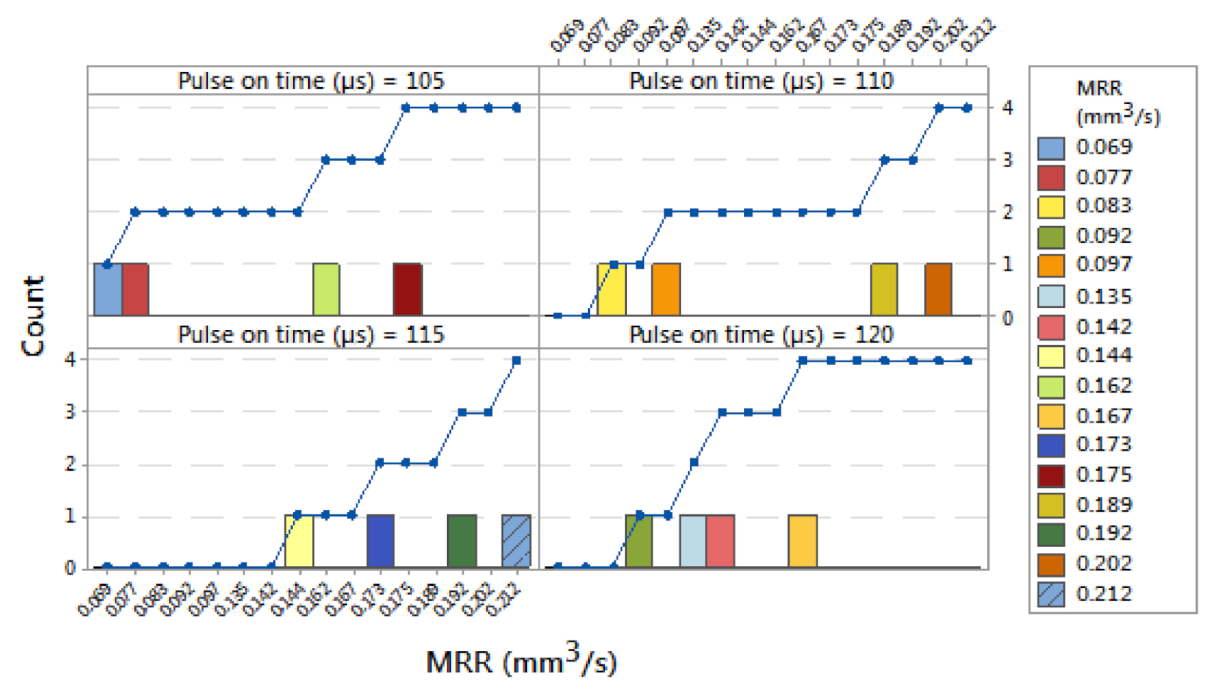

Figure 4. Pareto chart of material removal rate by pulse on time. 
Figure 5 illustrates the Pareto chart of material removal rate by pulse off time. Applying pulse off time of $40 \mu$ s produced MRRs of 0.069 and $0.092 \mathrm{~mm}^{3} / \mathrm{s}$. Increasing the pulse off time from 40 to $50 \mu \mathrm{s}$ acquired an MRR of $0.083 \mathrm{~mm}^{3} / \mathrm{s}$, continually influencing pulse off time of $60 \mu \mathrm{s}$ attained an MRR of $0.077 \mathrm{~mm}^{3} / \mathrm{s}$. Finally, the pulse off time of $70 \mu \mathrm{s}$ registered an MRR of $0.097 \mathrm{~mm}^{3} / \mathrm{s}$. Among the four levels of pulse off time, the $70 \mu \mathrm{s}$ of pulse off time offered the maximum MRR such as $0.097 \mathrm{~mm}^{3} / \mathrm{s}$. Figure 6 illustrates the Pareto chart of material removal rate by current (Amps) by supplying different current levels such as 3, 6, 9 and 12 Amps. The 3 Amps current recorded a material removal rate of $0.069 \mathrm{~mm}^{3} / \mathrm{s}$, applying 6 Amps of current obtained an MRR of $0.092 \mathrm{~mm}^{3} / \mathrm{s}$. Increasing to 9 Amps of current offered $0.077 \mathrm{~mm}^{3} / \mathrm{s}$ of MRR. Finally, the use of 12 Amps current can obtained an MRR of $0.083 \mathrm{~mm}^{3} / \mathrm{s}$. In all current levels, 6 Amps of current produced the maximum MRR such as $0.092 \mathrm{~mm}^{3} / \mathrm{s}$. All the minimum values of material removal rate reflected the changing parameters.

\section{Pareto Chart of MRR $\left(\mathrm{mm}^{3} / \mathrm{s}\right)$ by Pulse off time $(\mu \mathrm{s})$}

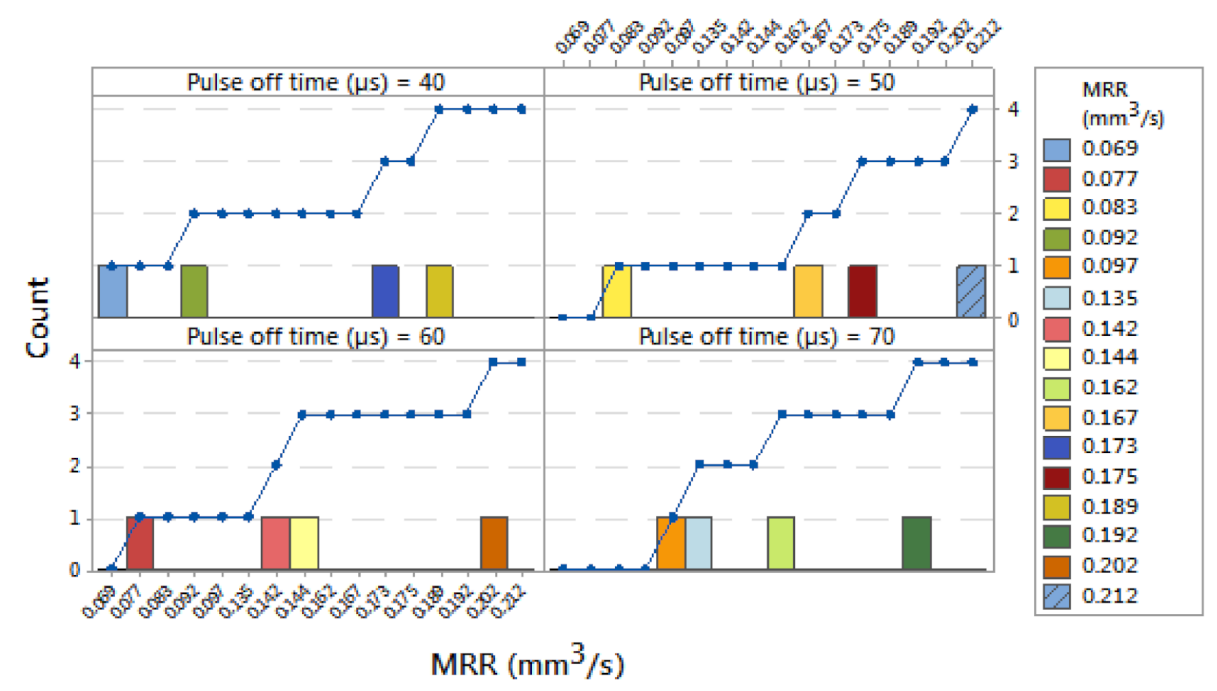

Figure 5. Pareto chart of material removal rate by pulse off time.

\section{Pareto Chart of MRR $\left(\mathrm{mm}^{3} / \mathrm{s}\right)$ by Current (Amps)}

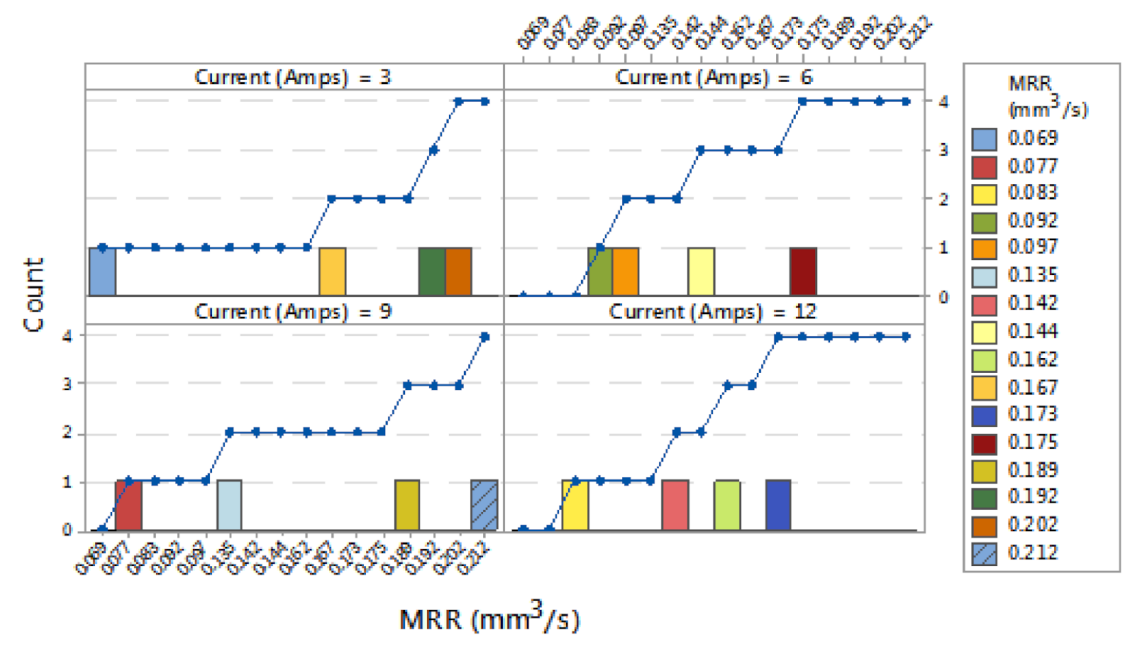

Figure 6. Pareto chart of material removal rate by current (Amps). 
Figure 7 illustrates the 3D bar plot of experimental vs. material removal rate effectively. Sixteen experimental runs were carried out and each run presents the minimum and maximum MRR of the AZ61 magnesium alloy hybrid composites. In this analysis, the minimum material removal rate was recorded as $0.069 \mathrm{~mm}^{3} / \mathrm{s}$ by use of $105 \mu$ s pulse on time, $40 \mu$ s pulse off time, $2 \mathrm{~m} / \mathrm{min}$ of wire feed rate and $3 \mathrm{Amps}$ of current rate. Similarly, maximum MRR was found to be $0.212 \mathrm{~mm}^{3} / \mathrm{s}$ by use of $115 \mu$ s pulse on time, $50 \mu$ s pulse off time, $8 \mathrm{~m} / \mathrm{min}$ of wire feed rate and 9 Amps of current rate. Influencing factors decided the excellent MRR.

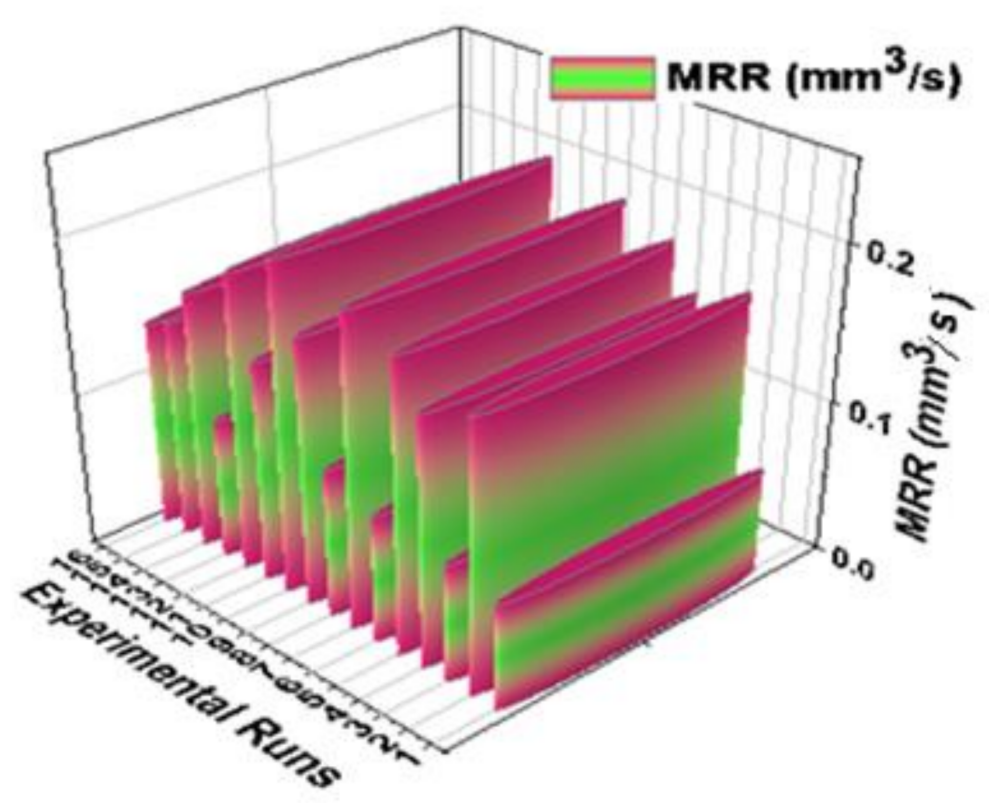

Figure 7. 3D bar plot of experimental vs. material removal rate.

Figure 8a shows the pulse on time ( $\mu \mathrm{s})$ vs. pulse off time ( $\mu \mathrm{s})$ contour plot. The maximum MRR was obtained as $0.2120 \mathrm{~mm}^{3} / \mathrm{s}$ from the influence of the pulse on time of $115 \mu \mathrm{s}$ and pulse off time of $50 \mu \mathrm{s}$. Increasing pulse on time slightly improved the MRR by the way of erosion. Figure $8 \mathrm{~b}$ shows the contour plot of pulse off time $\mu \mathrm{s}$ vs. wire feed rate $\mathrm{m} / \mathrm{min}$. The maximum MRR was obtained with wire feed rate of $8 \mathrm{~m} / \mathrm{min}$ and the pulse off time of $50 \mu \mathrm{s}$. The highest wire feed rate increases the erosion rate, hence MRR was achieved at higher rate such as $0.194 \mathrm{~mm}^{3} / \mathrm{s}$. Figure $8 \mathrm{c}$ shows the wire feed rate $(\mathrm{m} / \mathrm{min})$ vs. current (Amps). The highest MRR was acquired at wire feed rate of $8 \mathrm{~m} / \mathrm{min}$ and the current of 10 Amps. In a similar manner, the wire feed rate was highly influenced as increasing the erosion rate finally obtained maximum MRR.

\subsection{Surface Roughness Analysis}

Figure 9 shows the surface roughness values of the all specimens visibly in the minimum and maximum ranges. Among the 16 specimens, the first specimen has a minimum surface roughness value of 1.0039 microns with influence of pulse on time of $105 \mu \mathrm{s}$, pulse off time of $40 \mu \mathrm{s}$, wire feed rate of $2 \mathrm{~m} / \mathrm{min}$ and current of 3 Amps. The specimen number 16 registered a maximum surface roughness value of 3.203 microns. The maximum surface roughness value was attained by the influence of pulse on time $(120 \mu \mathrm{s})$, pulse off time $(70 \mu \mathrm{s}), 2 \mathrm{~m} / \mathrm{min}$ of wire feed rate and 9 Amps of current. It can be clearly revealed that the increase of pulse on time, pulse off time and the current rate increases the surface roughness. The average surface roughness value was found as 2.442 microns. It can be obtained in the use of L16 Orthogonal Array (OA). From the statistical analysis, the experimental runs 5, 9 and 13 provide the surface roughness values less than 2 microns. On the contrary, the maximum surface roughness above 3 microns was identified in 14,15 and 16 experimental runs. 
(a)

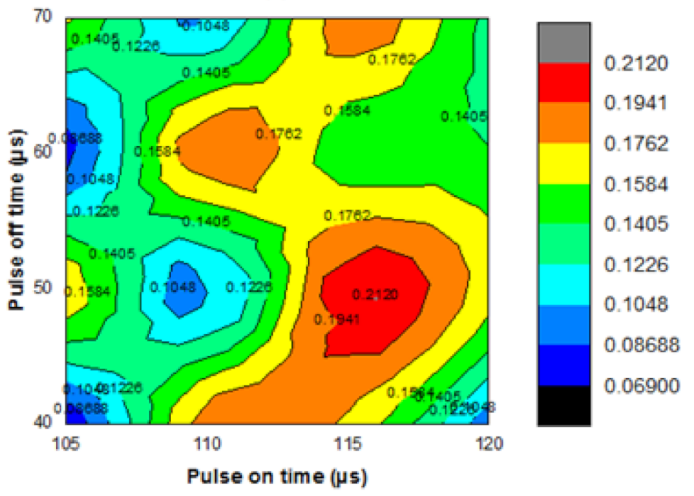

(b)

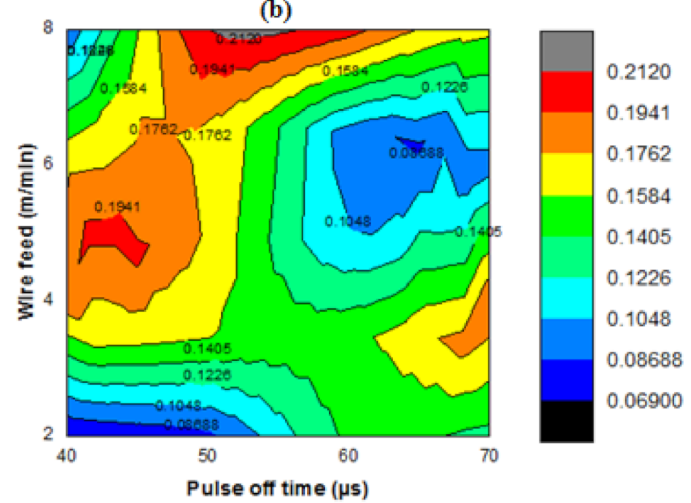

(c)

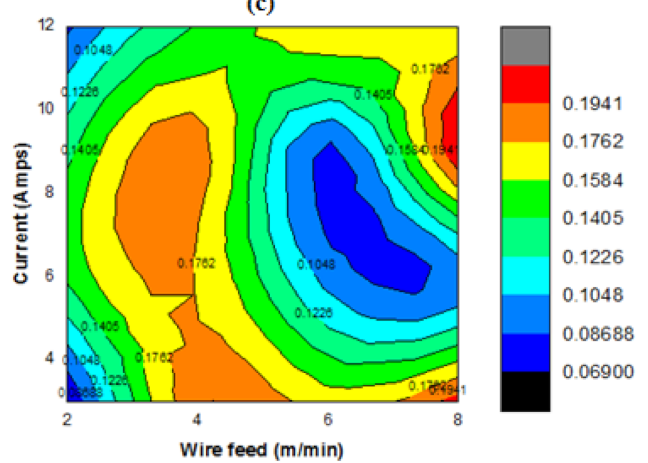

Figure 8. Contour plot of (a) pulse on time ( $\mu \mathrm{s})$ vs. pulse off time, $(\mathbf{b})$ pulse off time ( $\mu \mathrm{s})$ vs. wire feed rate $(\mathrm{m} / \mathrm{min})$ and $(\mathbf{c})$ wire feed rate $(\mathrm{m} / \mathrm{min})$ vs. current (Amps).

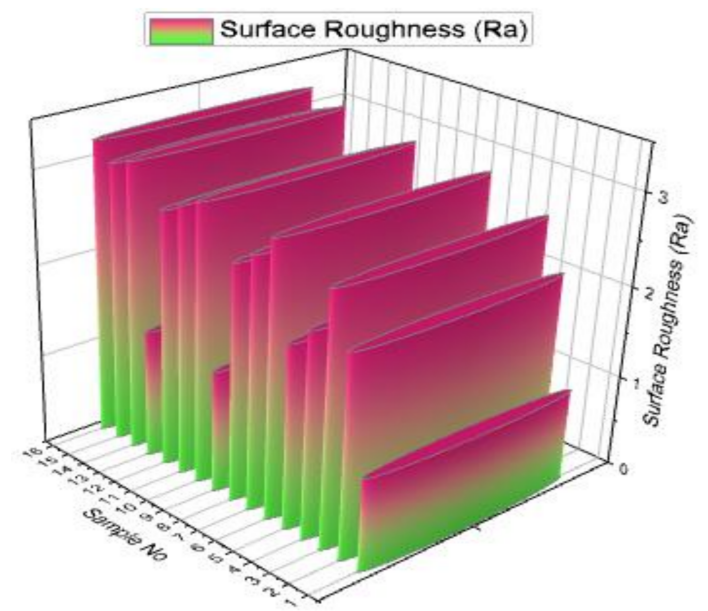

Figure 9. 3D bar plot of experimental vs. surface roughness graph. 
Table 7 points out the surface roughness value of the all specimens efficiently. The minimum and maximum values of surface roughness are 1.003942 and 3.203942 microns.

Table 7. Outline of surface roughness results.

\begin{tabular}{cccc}
\hline & Surface Roughness (Ra), microns & \\
\hline S. No & Test-1 & Test-2 & Average \\
\hline 1 & 0.66813 & 1.339755 & 1.003942 \\
2 & 2.37413 & 2.001755 & 2.187942 \\
3 & 2.94513 & 2.486755 & 2.715942 \\
4 & 2.27413 & 2.155755 & 2.214942 \\
5 & 2.30513 & 1.682755 & 1.993942 \\
6 & 2.71513 & 3.190755 & 2.952942 \\
7 & 2.67913 & 2.740755 & 2.709942 \\
8 & 2.66313 & 2.435755 & 2.549442 \\
9 & 1.53913 & 1.120755 & 1.329942 \\
10 & 2.87013 & 3.128755 & 2.999442 \\
11 & 3.13613 & 2.651755 & 2.893942 \\
12 & 2.83613 & 2.707755 & 2.771942 \\
13 & 1.31813 & 1.471755 & 1.394942 \\
14 & 3.09813 & 3.148755 & 3.123442 \\
15 & 3.06013 & 3.015755 & 3.037942 \\
16 & 3.49613 & 2.911755 & 3.203942 \\
\hline
\end{tabular}

Table 8 illustrates the response table for signal to noise ratios of the surface roughness test. From this table, the pulse off time parameter has the highest influencing factor among all four parameters, further the pulse on time, current and wire feed rate. In surface roughness analysis, the optimal parameters were registered as $105 \mu$ s of pulse on time, $40 \mu$ s of pulse off time, $8 \mathrm{~m} / \mathrm{min}$ of wire feed rate and 6 Amps of current.

Table 8. Response table for signal to noise ratios (surface roughness).

\begin{tabular}{ccccc}
\hline Level & Pulse on Time $(\boldsymbol{\mu s})$ & Pulse off Time $(\boldsymbol{\mu s})$ & Wire Feed Rate $(\mathbf{m} / \mathbf{m i n})$ & Current (Amps) \\
\hline 1 & -5.605 & -2.849 & -7.196 & -6.860 \\
2 & -8.047 & -8.910 & -7.826 & -6.763 \\
3 & -7.526 & -9.055 & -7.294 & -8.582 \\
4 & -8.137 & -8.501 & -7.000 & -7.110 \\
Delta & 2.532 & 6.206 & 0.826 & 1.819 \\
Rank & 2 & 1 & 4 & 3 \\
\hline
\end{tabular}

\subsection{Tensile Strength Analysis}

Table 9 presents the experimental summary of the tensile strength involving the four parameters and four levels; the result of tensile strength was illustrated clearly. The maximum tensile strength was registered as $245 \mathrm{MPa}$ with influencing of reinforcement of $2 \%$, stirring speed of $600 \mathrm{rpm}$, time of stirring $30 \mathrm{~min}$ and processing temperature $800{ }^{\circ} \mathrm{C}$. Increasing stirring time produced the better results.

Table 10 presents the response table for signal to noise ratios of tensile strength. Among four parameters, the stirring speed highly influenced the results in contrast to other parameters. Further, the time of stirring is the second factor of influence in tensile strength, continually followed by processing temperature and reinforcement $\%$. 
Table 9. Experimental summary of tensile strength.

\begin{tabular}{|c|c|c|c|c|c|}
\hline Exp. Trials & $\begin{array}{c}\text { Reinforcement } \\
(\%)\end{array}$ & $\begin{array}{l}\text { Stirring Speed } \\
(\mathrm{rpm})\end{array}$ & $\begin{array}{l}\text { Time of Stirring } \\
\text { (min) }\end{array}$ & $\begin{array}{c}\text { Process Temperature } \\
\left({ }^{\circ} \mathrm{C}\right)\end{array}$ & $\begin{array}{c}\text { Tensile Strength } \\
\text { (MPa) }\end{array}$ \\
\hline 1 & 2 & 450 & 15 & 650 & 208 \\
\hline 2 & 2 & 500 & 20 & 700 & 214 \\
\hline 3 & 2 & 550 & 25 & 750 & 236 \\
\hline 4 & 2 & 600 & 30 & 800 & 245 \\
\hline 5 & 4 & 450 & 20 & 750 & 217 \\
\hline 6 & 4 & 500 & 15 & 800 & 228 \\
\hline 7 & 4 & 550 & 30 & 650 & 237 \\
\hline 8 & 4 & 600 & 25 & 700 & 208 \\
\hline 9 & 6 & 450 & 25 & 800 & 219 \\
\hline 10 & 6 & 500 & 30 & 750 & 220 \\
\hline 11 & 6 & 550 & 15 & 700 & 238 \\
\hline 12 & 6 & 600 & 20 & 650 & 244 \\
\hline 13 & 8 & 450 & 30 & 700 & 236 \\
\hline 14 & 8 & 500 & 25 & 650 & 230 \\
\hline 15 & 8 & 550 & 20 & 800 & 241 \\
\hline 16 & 8 & 600 & 15 & 750 & 218 \\
\hline
\end{tabular}

Table 10. Response table for signal to noise ratios (tensile strength).

\begin{tabular}{ccccc}
\hline Level & Reinforcement(\%) & Stirring Speed (rpm) & Time of Stirring (min) & ProcessTemperature $\left({ }^{\circ} \mathbf{C}\right)$ \\
\hline 1 & 47.05 & 46.84 & 46.96 & 47.21 \\
2 & 46.94 & 46.96 & 47.18 & 46.99 \\
3 & 47.23 & 47.53 & 46.97 & 46.95 \\
4 & 47.28 & 47.17 & 47.40 & 47.35 \\
Delta & 0.34 & 0.69 & 0.44 & 0.40 \\
Rank & 4 & 1 & 2 & 3 \\
\hline
\end{tabular}

Larger is better.

Figure 10 shows the main effect plot for SN (signal to noise) ratios of the tensile strength. The increasing reinforcement percentage increased the tensile strength, $8 \%$ of reinforcement offered high tensile strength. Among all stirring speed conditions, the third level $550 \mathrm{rpm}$ provided good tensile strength. Minimum tensile strength was viewed in the influence of minimum time of stirring. By increasing the stirring time from 25 to $30 \mathrm{~min}$ the higher tensile strengths were obtained [42]. In all processing temperatures, the normal tensile strength was obtained, and $800{ }^{\circ} \mathrm{C}$ provided the maximum tensile strength. Optimal parameters were obtained for the tensile strength as $8 \%$ of reinforcement, $550 \mathrm{rpm}$ of stirring speed, $30 \mathrm{~min}$ of stirring time period and $800^{\circ} \mathrm{C}$ of processing temperature.

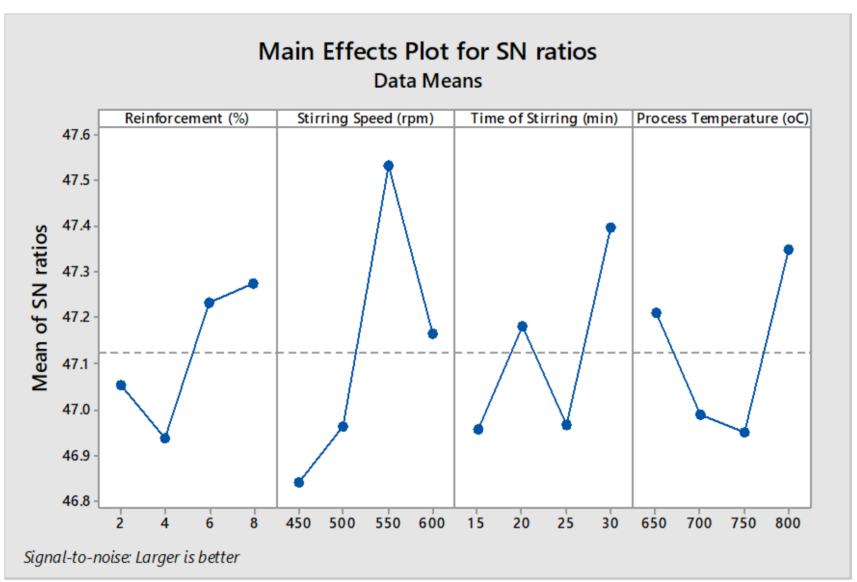

Figure 10. Main effect plot for $\mathrm{SN}$ ratios (tensile strength). 
Figure 11 illustrates the 3D bar plot of tensile strength influenced by two parameters such as reinforcement and stirring speed. This plot shows the increase of stirring speed, as well as increase of reinforcement percentage, highly influenced the increase of tensile strength. Figure 12 presents the two parameters correlation. The minimum stirring speed and the maximum stirring time offered superior tensile strength. Figure 13 presents the correlation between time of stirring and the process temperature. This plot clearly shows that $30 \mathrm{~min}$ of time of stirring and $800{ }^{\circ} \mathrm{C}$ of processing temperature provided the better tensile strength. Figure 14 illustrates the interaction between two parameters such as process temperature and reinforcement $\%$. The processing temperature of $800{ }^{\circ} \mathrm{C}$ and the $8 \%$ of reinforcement offered the high tensile strength.

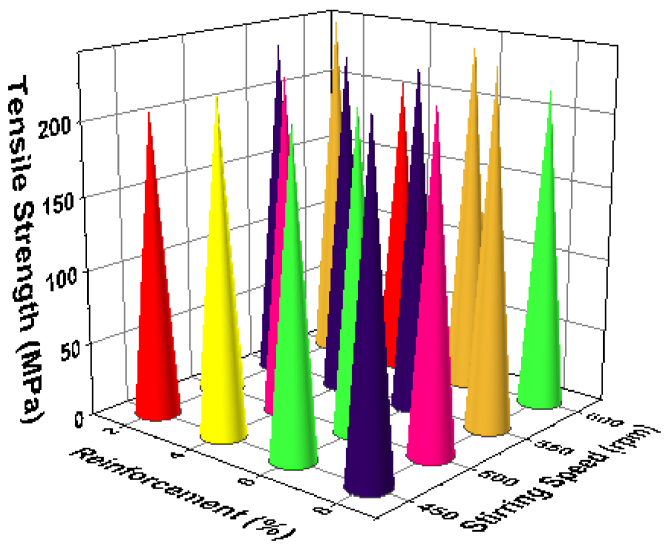

Figure 11. 3D bar plot: reinforcement vs. stirring.

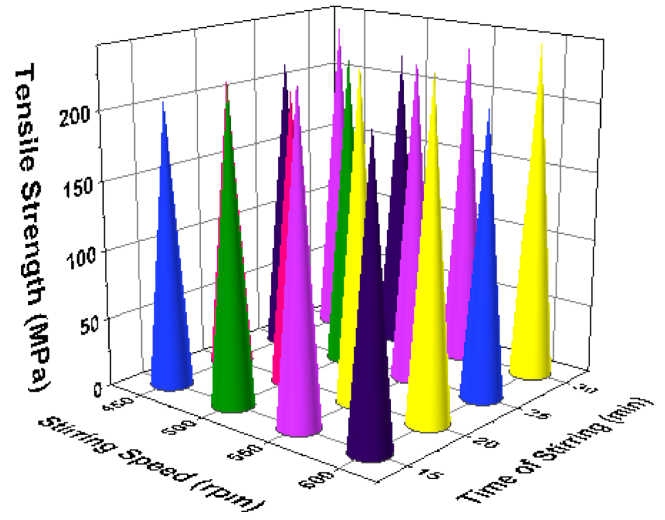

Figure 12. 3D bar plot: stirring speed vs. time of stirring.

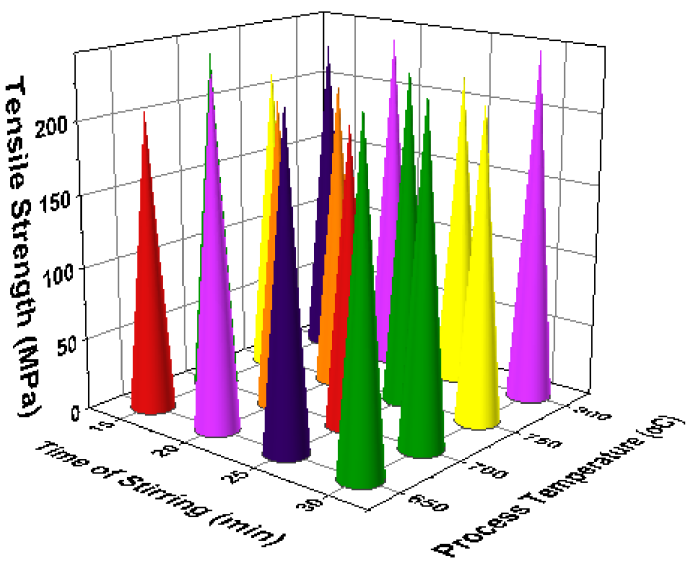

Figure 13. 3D bar plot: time of stirring vs. process temperature. 


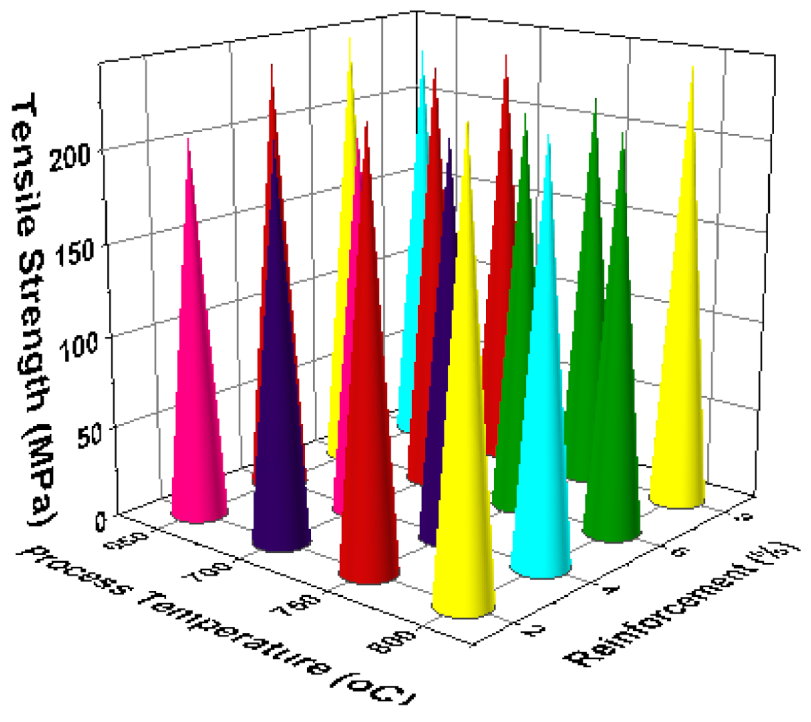

Figure 14. 3D bar plot: process temperature vs. reinforcement $\%$.

Figure 15 illustrates the 3D bar plot of experimental vs. tensile strength of the study. In all 16 experimental trials, each trail visibly showed the minimum and maximum tensile strength of the AZ61 hybrid composites. In most of the experimental runs, the tensile strength was nearer to others. For this examination the maximum tensile strength was recorded as $245 \mathrm{MPa}$. On the contrary, the minimum tensile strength was achieved as $208 \mathrm{MPa}$. From this analysis the multiple runs offered excellent tensile strength. Stirring speed highly influenced modification of the tensile strength.

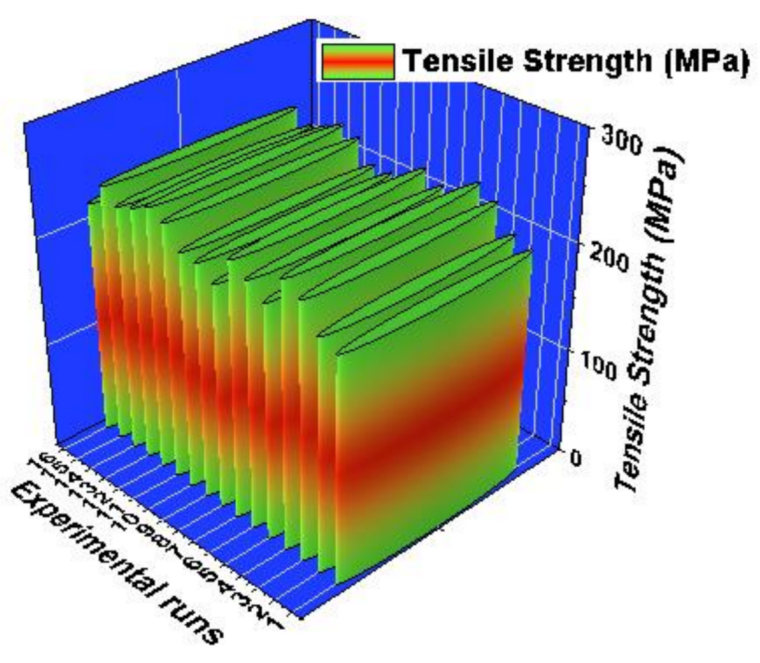

Figure 15. 3D bar plot: experimental runs vs. tensile strength.

\subsection{Micro Hardness Analysis}

Table 11 presents the micro hardness experimental summary. In this summary, the selected parameters are presented with their levels and the output response values such as micro hardness. Results of micro hardness values were clearly presented in the table. Higher values of micro hardness were recorded as $206.475 \mathrm{HV}$ through the influence of reinforcement of $4 \%$, stirring speed of $550 \mathrm{rpm}$, time of stirring $30 \mathrm{~min}$ and processing temperature $650{ }^{\circ} \mathrm{C}$. In conclusion, the increase of process temperature can produce enhanced results. 
Table 11. Experimental summary of micro hardness.

\begin{tabular}{|c|c|c|c|c|c|}
\hline Exp. Trials & $\begin{array}{c}\text { Reinforcement } \\
(\%)\end{array}$ & $\begin{array}{l}\text { Stirring Speed } \\
(\mathrm{rpm})\end{array}$ & $\begin{array}{c}\text { Time of Stirring } \\
\text { (min) }\end{array}$ & $\begin{array}{c}\text { Process Temperature } \\
\left({ }^{\circ} \mathrm{C}\right)\end{array}$ & $\begin{array}{c}\text { Micro Hardness } \\
\text { (HV) }\end{array}$ \\
\hline 1 & 2 & 450 & 15 & 650 & 182.40 \\
\hline 2 & 2 & 500 & 20 & 700 & 173.65 \\
\hline 3 & 2 & 550 & 25 & 750 & 194.27 \\
\hline 4 & 2 & 600 & 30 & 800 & 183.12 \\
\hline 5 & 4 & 450 & 20 & 750 & 168.54 \\
\hline 6 & 4 & 500 & 15 & 800 & 201.27 \\
\hline 7 & 4 & 550 & 30 & 650 & 206.45 \\
\hline 8 & 4 & 600 & 25 & 700 & 195.17 \\
\hline 9 & 6 & 450 & 25 & 800 & 188.67 \\
\hline 10 & 6 & 500 & 30 & 750 & 181.42 \\
\hline 11 & 6 & 550 & 15 & 700 & 175.38 \\
\hline 12 & 6 & 600 & 20 & 650 & 199.24 \\
\hline 13 & 8 & 450 & 30 & 700 & 192.71 \\
\hline 14 & 8 & 500 & 25 & 650 & 204.73 \\
\hline 15 & 8 & 550 & 20 & 800 & 206.18 \\
\hline 16 & 8 & 600 & 15 & 750 & 185.41 \\
\hline
\end{tabular}

Table 12 presents the response table for signal to noise ratios of micro hardness. This table properly showed the parameter influences and the levels of influence. Amongst the four process parameters, the process temperature parameter was extremely influenced and had the chief role in decision of micro hardness. The other three factors were influenced; compared to process temperature, they contributed a small amount. The second, third and fourth parameter influences are reinforcement \%, stirring speed and time of stirring, respectively [43-47].

Table 12. Response table for signal to noise ratios (micro hardness).

\begin{tabular}{ccccc}
\hline Level & $\begin{array}{c}\text { Reinforcement } \\
(\%)\end{array}$ & $\begin{array}{c}\text { Stirring Speed } \\
(\mathbf{r p m})\end{array}$ & $\begin{array}{c}\text { Time of Stirring } \\
(\mathbf{m i n})\end{array}$ & $\begin{array}{c}\text { Process Temperature } \\
\left({ }^{\circ} \mathbf{C}\right)\end{array}$ \\
\hline 1 & 45.26 & 45.24 & 45.38 & 45.89 \\
2 & 45.68 & 45.52 & 45.40 & 45.29 \\
3 & 45.39 & 45.81 & 45.79 & 45.21 \\
4 & 45.85 & 45.60 & 45.61 & 45.78 \\
Delta & 0.59 & 0.57 & 0.40 & 0.68 \\
Rank & 2 & 3 & 4 & 1 \\
\hline
\end{tabular}

Larger is better.

Figure 16 shows the main effect plot for $\mathrm{SN}$ ratios of micro hardness test; in this test, the four parameters partaking were discernibly presented. In reinforcement percentage involvement, the result values are in a zigzag manner such as increasing and decreasing of micro hardness values in a cyclic manner. Finally, the $8 \%$ of reinforcement offered the higher micro hardness values. In stirring speed parameter contribution, the increasing trends increase the micro hardness values. Further increases from 550 to $600 \mathrm{rpm}$ led to decreased micro hardness values. The $550 \mathrm{rpm}$ provided better micro hardness values. Considering the time of stirring parameters, the $25 \mathrm{~min}$ of stirring time offered excellent micro hardness values. Minimum level of temperature produces higher hardness values. Optimal parameters were obtained as $8 \%$ of reinforcement, $500 \mathrm{rpm}$ of stirring speed, and $25 \mathrm{~min}$ of timing of stirring and $650{ }^{\circ} \mathrm{C}$ of processing temperature. 


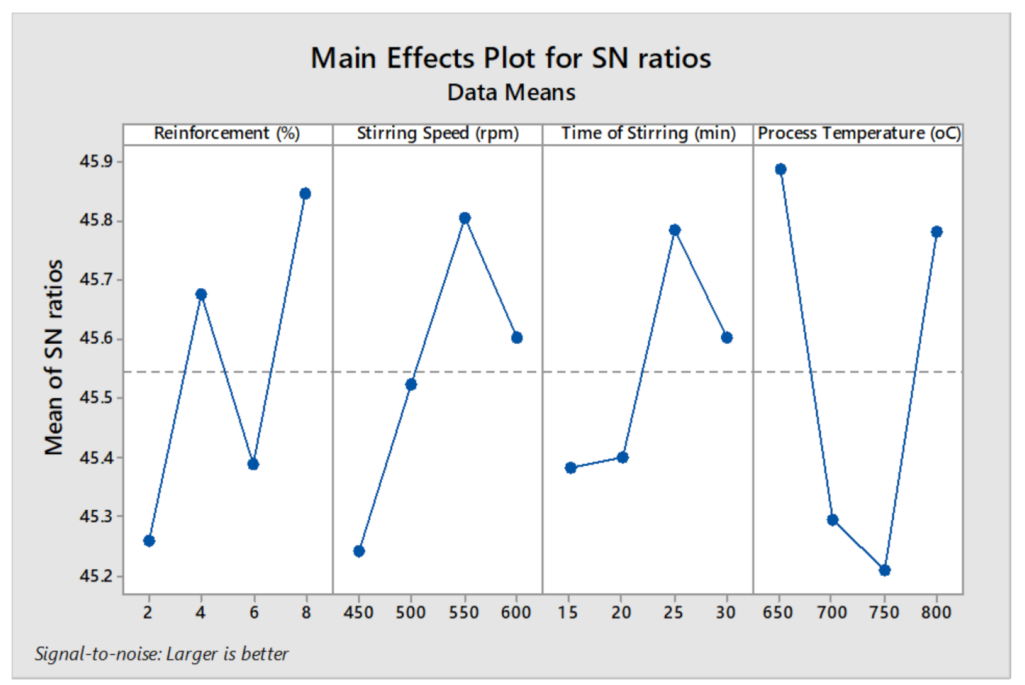

Figure 16. Main effect plot for SN ratios (micro hardness).

Figure 17 illustrates the 3D bar plot of the correlation between reinforcement and stirring speeds in the micro hardness analysis. Increase of stirring speed (550 rpm) and increase of reinforcement percentage $(8 \%)$ offered excellent micro hardness values (around $200 \mathrm{HV}$ ). Figure 18 shows the correlation between stirring speed and time of stirring of the micro hardness analysis. The third level of stirring speed and minimum level of time of stirring encourage the better micro hardness values such as near to $200 \mathrm{HV}$. Figure 19 illustrates the relationship among the time of stirring and process temperature evidently. Influence of $25 \mathrm{~min}$ of time of stirring and $650{ }^{\circ} \mathrm{C}$ of processing temperature offered the higher levels of micro hardness values. Minimum micro hardness was recorded by using of $15 \mathrm{~min}$ of time of stirring and $750{ }^{\circ} \mathrm{C}$ of processing temperature. Figure 20 illustrates that for the connection between process temperature and reinforcement, the maximum micro hardness was recorded with influence of $750{ }^{\circ} \mathrm{C}$ of processing temperature and $8 \%$ of reinforcement.

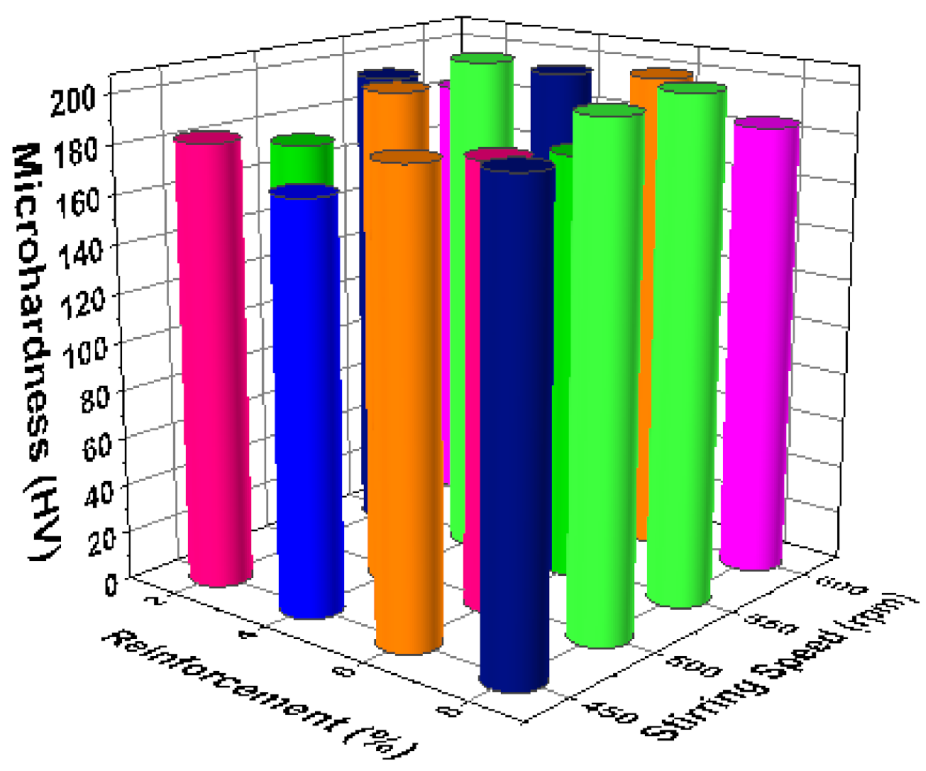

Figure 17. 3D bar plot: reinforcement vs. stirring speed. 


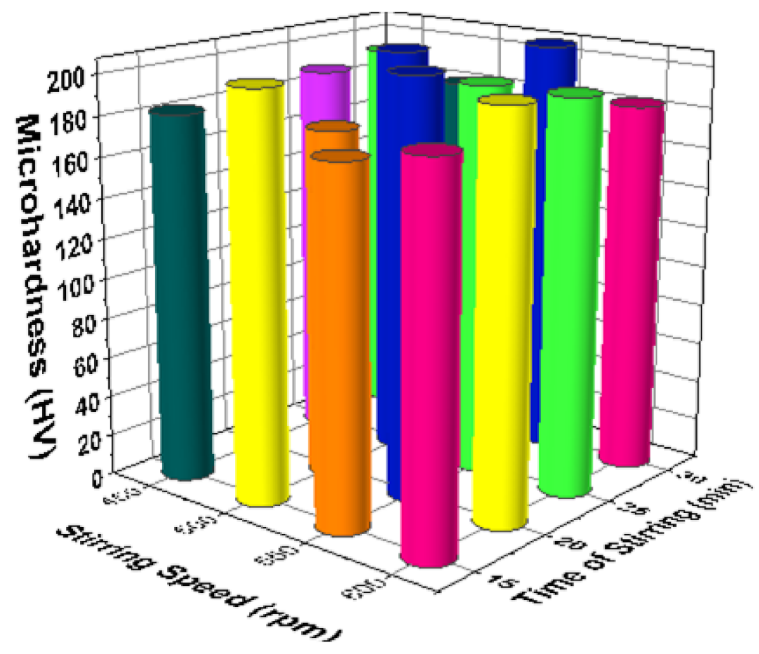

Figure 18. 3D bar plot: stirring speed vs. time of stirring.

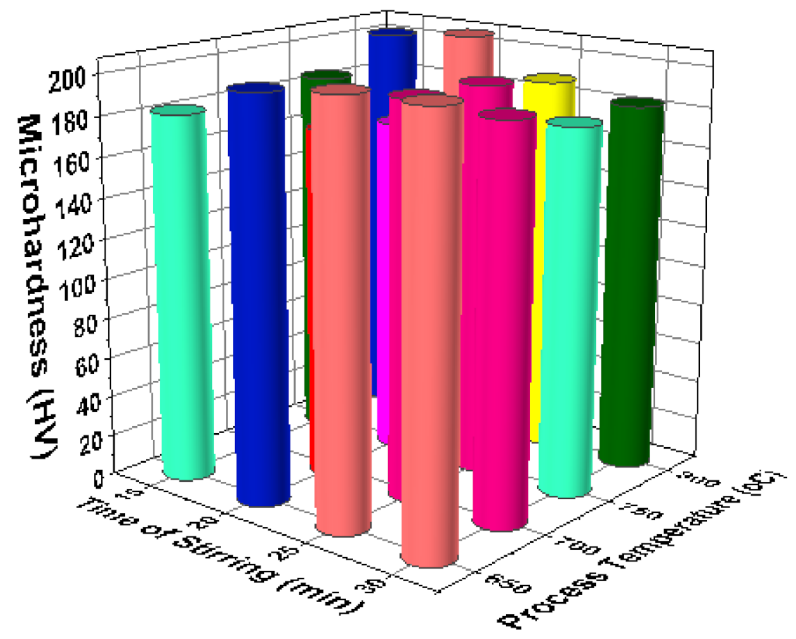

Figure 19. 3D bar plot: time of stirring vs. process temperature.

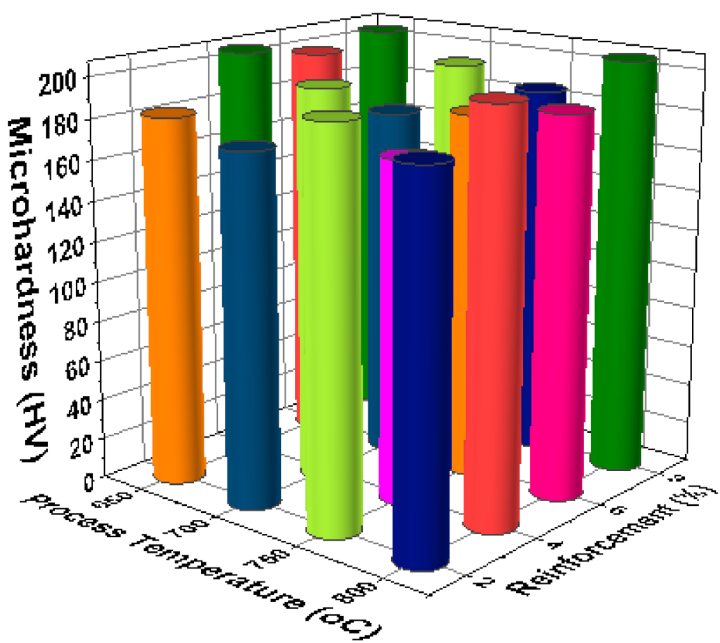

Figure 20. 3D bar plot: process temperature vs. reinforcement $\%$. 
Figure 21 shows the 3D bar plot of experimental vs. micro hardness of the analysis. From all 16 experimental trials, each trial obviously exhibited the minimum and maximum micro hardness of the AZ61 hybrid composites. In most of the experimental trials, the micro hardness values slightly deviated from each other, For this inspection the maximum micro hardness was documented as $206.45 \mathrm{HV}$ by the way of $4 \%$ of reinforcement, $550 \mathrm{rpm}$ of stirring speed, $30 \mathrm{~min}$ of time of stirring and $650{ }^{\circ} \mathrm{C}$ process temperature. On other hand, the minimum micro hardness was registered as $168.54 \mathrm{HV}$ with the effect of $4 \%$ of reinforcement, $450 \mathrm{rpm}$ of stirring speed, $20 \mathrm{~min}$ of time of stirring and $750{ }^{\circ} \mathrm{C}$ process temperature. From this analysis, the several runs presented the exceptional micro hardness values. In all factors, the processing temperature extremely influenced the micro hardness.

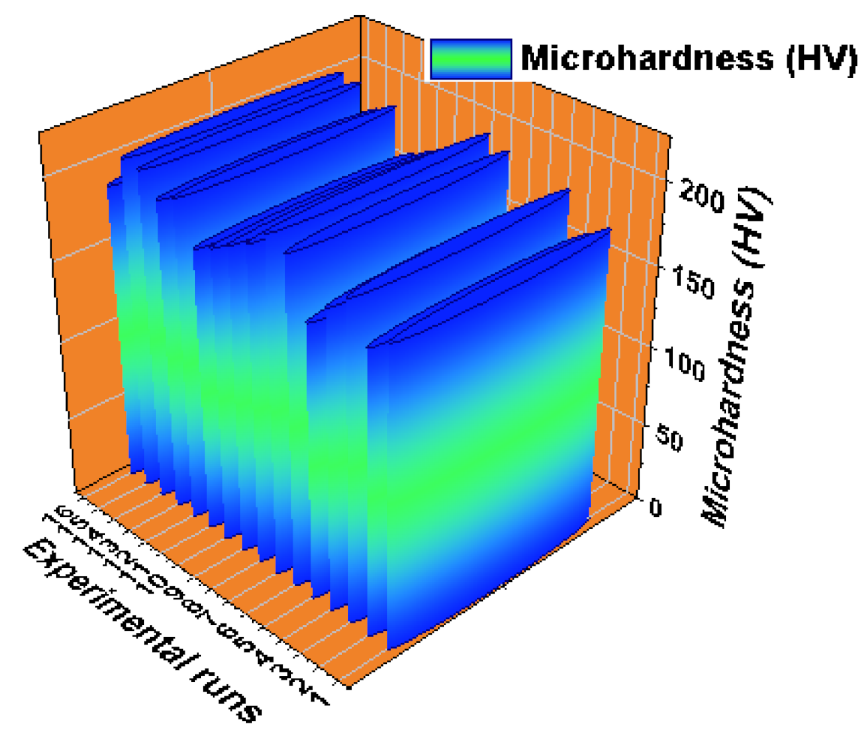

Figure 21. 3D bar plot: experimental runs vs. micro hardness.

\section{Conclusions}

The AZ61 magnesium alloy was produced by stir casting process with addition of born carbide + silicon carbide and the plate was made from the stir casting process successfully. The casted magnesium alloy was machined by wire cut EDM process. Surface roughness of the sliced out specimens in the casted magnesium alloy through wire cut EDM was checked using a surface roughness tester. The material removal rate, tensile strength and micro hardness tests were successfully carried out and the result of this investigation is as follows:

- The maximum material removal rate was obtained as $0.212 \mathrm{~mm}^{3} / \mathrm{s}$ influence of pulse on time of $115 \mu \mathrm{s}$, pulse off time of $50 \mu \mathrm{s}$. The contour plot illustrates the maximum MRR obtained as wire feed rate of $8 \mathrm{~m} / \mathrm{min}$ and the pulse off time as $50 \mu \mathrm{s}$. The wire feed rate of $8 \mathrm{~m} / \mathrm{min}$ and the current as 9 Amps offered good MRR. The minimum material removal rate was obtained as $0.069 \mathrm{~mm}^{3} / \mathrm{s}$. Increasing of pulse on time slightly improved the MRR by the way of erosion. The highest wire feed rate increased the erosion rate, hence the MRR was achieved at the higher rate.

- The minimum and maximum values of surface roughness were obtained as 1.003942 and 3.203942 microns. From out of 16 specimens, the first specimen had minimum surface roughness value such as 1.0039 microns influenced by pulse on time of $105 \mu \mathrm{s}$, pulse off time of $40 \mu \mathrm{s}$, wire feed rate of $2 \mathrm{~m} / \mathrm{min}$ and current of 3 Amps. The pulse off time parameter had the highest influencing factor among all four parameters. In surface roughness analysis, the optimal parameters were recorded as $105 \mu$ s of pulse on time, $40 \mu \mathrm{s}$ of pulse off time, $8 \mathrm{~m} / \mathrm{min}$ of wire feed rate and 6 Amps of current.

- From the tensile test, the maximum tensile strength was recorded as $245 \mathrm{MPa}$ with influence of reinforcement of $2 \%$, stirring speed of $600 \mathrm{rpm}$, time of stirring $30 \mathrm{~min}$ 
and processing temperature of $800{ }^{\circ} \mathrm{C}$. Optimal parameters of the tensile test were obtained as $8 \%$ of reinforcement, $550 \mathrm{rpm}$ of stirring speed, $30 \mathrm{~min}$ of stirring time period and $800{ }^{\circ} \mathrm{C}$ of processing temperature.

- In the micro hardness test, the higher values of micro hardness were recorded as 206.475 HV through influence of $4 \%$ of reinforcement, stirring speed of $550 \mathrm{rpm}$, time of stirring $30 \mathrm{~min}$ and processing temperature of $650{ }^{\circ} \mathrm{C}$. Finally, the increase of process temperature in the stir casting process can be reflected in the enhanced results of surface roughness. Optimal parameters of the micro hardness test were obtained as $8 \%$ of reinforcement, $500 \mathrm{rpm}$ of stirring speed, $25 \mathrm{~min}$ of stirring time and $650{ }^{\circ} \mathrm{C}$ of processing temperature.

Author Contributions: Conceptualization, T.S. and A.K.; Data curation, V.M.; Formal analysis, T.S., V.M., A.A. and C.A.S.; Funding acquisition, A.K. and A.A.; Investigation, R.S. and A.A; Methodology, T.S., K.A., A.A. and C.A.S.; Project administration, T.S., V.M., R.S., A.A., S.A. and C.A.S.; Resources, K.A., R.S. and A.A.; Software, A.A. and S.A.; Supervision, R.S. and A.K.; Validation, A.K.; Visualization, V.M., R.S. and C.A.S.; Writing-original draft, T.S., V.M., K.A., R.S. and S.A.; Writing-review \& editing, K.A., A.K. and S.A. All authors have read and agreed to the published version of the manuscript.

Funding: This research was funded by Deanship of Scientific Research at King Khalid University, grant number RGP. 2/127/42.

Institutional Review Board Statement: Not applicable.

Informed Consent Statement: Not applicable.

Data Availability Statement: All the data is available within the manuscript.

Acknowledgments: The authors extend their appreciation to the Deanship of Scientific Research at King Khalid University, Saudi Arabia for funding this work through the Research Group Program under grant no. R.G.P.2/127/42.

Conflicts of Interest: The authors declare no conflict of interest.

\section{References}

1. Huang, S.-J.; Subramani, M.; Chiang, C.-C. Effect of hybrid reinforcement on microstructure and mechanical properties of AZ61 magnesium alloy processed by stir casting method. Compos. Commun. 2021, 25, 100772. [CrossRef]

2. Chaudhari, R.; Vora, J.J.; Patel, V.; De Lacalle, L.N.L.; Parikh, D.M. Surface Analysis of Wire-Electrical-Discharge-MachiningProcessed Shape-Memory Alloys. Materials 2020, 13, 530. [CrossRef] [PubMed]

3. Qin, Y.J.; Pan, Q.L.; He, Y.B.; Li, W.B.; Liu, X.Y.; Fan, X. Artificial Neural Network Modeling to Evaluate and Predict the Deformation Behavior of ZK60 Magnesium Alloy During Hot Compression. Mater. Manuf. Process. 2010, 25, 539-545. [CrossRef]

4. Rajmohan, T.; Palanikumar, K.; Arumugam, S. Synthesis and characterization of sintered hybrid aluminium matrix composites reinforced with nanocopper oxide particles and microsilicon carbide particles. Compos. Part B Eng. 2014, 59, 43-49. [CrossRef]

5. Shen, M.; Wang, X.; Ying, T.; Wu, K.; Song, W. Characteristics and mechanical properties of magnesium matrix composites reinforced with micron/submicron/nano SiC particles. J. Alloy. Compd. 2016, 686, 831-840. [CrossRef]

6. Poovazhagan, L.; Kalaichelvan, K.; Sornakumar, T. Processing and Performance Characteristics of Aluminum-Nano Boron Carbide Metal Matrix Nanocomposites. Mater. Manuf. Process. 2016, 31, 1275-1285. [CrossRef]

7. Zhang, G.; Zhang, Z.; Guo, J.; Ming, W.; Li, M.; Huang, Y. Modeling and Optimization of Medium-Speed WEDM Process Parameters for Machining SKD11. Mater. Manuf. Process. 2013, 28, 1124-1132. [CrossRef]

8. Chaudhari, R.; Vora, J.J.; Patel, V.; De Lacalle, L.N.L.; Parikh, D.M. Effect of WEDM Process Parameters on Surface Morphology of Nitinol Shape Memory Alloy. Materials 2020, 13, 4943. [CrossRef]

9. Rao, T.B.; Krishna, A.G. Simultaneous optimization of multiple performance characteristics in WEDM for machining ZC63/SiC $\mathrm{p}$ MMC. Adv. Manuf. 2013, 1, 265-275.

10. Mandal, A.; Dixit, A.R.; Das, A.K.; Mandal, N. Modeling and Optimization of Machining Nimonic C-263 Superalloy using Multicut Strategy in WEDM. Mater. Manuf. Process. 2015, 31, 860-868. [CrossRef]

11. Gopal, P.M.; Prakash, K.S.; Jayaraj, S. WEDM of Mg/CRT/BN composites: Effect of materials and machining parameters. Mater. Manuf. Process. 2018, 33, 77-84. [CrossRef]

12. Rao, T.B.; Krishna, A.G. Selection of optimal process parameters in WEDM while machining Al7075/SiCp metal matrix composites. Int. J. Adv. Manuf. Technol. 2014, 73, 299-314. [CrossRef]

13. Dhandapani, S.; Rajmohan, T.; Palanikumar, K.; Charan, M. Synthesis and characterization of dual particle (MWCT $\left.+\mathrm{B}_{4} \mathrm{C}\right)$ reinforced sintered hybrid aluminum matrix composites. Part. Sci. Technol. 2016, 34, 255-262. [CrossRef] 
14. Morovvati, M.R.; Lalehpour, A.; Esmaeilzare, A. Effect of nano/micro $\mathrm{B}_{4} \mathrm{C}$ and $\mathrm{SiC}$ particles on fracture properties of aluminum 7075 particulate composites under chevron-notch plane strain fracture toughness test. Mater. Res. Express 2016, 3, 125026. [CrossRef]

15. Kumar, N.; Gautam, R.K.; Mohan, S. In-situ development of $\mathrm{ZrB}_{2}$ particles and their effect on microstructure and mechanical properties of AA5052 metal-matrix composites. Mater. Des. 2015, 80, 129-136. [CrossRef]

16. Garg, S.; Manna, A.; Jain, A. An experimental investigation and parametric optimization for wire $\mathrm{EDM}$ of $\mathrm{Al}-5 \% \mathrm{ZrO} 2 \mathrm{particulate}$ reinforced metal matrix composite. Int. J. Mech. Mater. Eng. 2012, 7, 136-145.

17. Daneshmand, S.; Masoudi, B. Investigation and optimization of the electro-discharge machining parameters of 2024 aluminum alloy and $\mathrm{Al} / 7.5 \% \mathrm{Al}_{2} \mathrm{O}_{3}$ particulate-reinforced metal matrix composite. Sci. Eng. Compos. Mater. 2018, 25, 159-172. [CrossRef]

18. Shadab, M.; Singh, R.; Rai, R. Multi-objective optimization of wire electrical discharge machining process parameters for Al5083/7\% B 4 C composite using metaheuristic techniques. Arab. J. Sci. Eng. 2019, 44, 591-601. [CrossRef]

19. Sathish, T. Performance Improvement of Base Fluid Heat Transfer medium using nano fluid particles. J. New Mater for Electrochem. Syst. 2020, 4, 235-243. [CrossRef]

20. Motorcu, A.R.; Ekici, E.; Kus, A. Investigation of the WEDM of $\mathrm{Al} / \mathrm{B}_{4} \mathrm{C} / \mathrm{Gr}$ reinforced hybrid composites using the Taguchi method and response surface methodology. Sci. Eng. Compos. Mater. 2016, 23, 435-445. [CrossRef]

21. Kumar, K.R.; Soms, N. Desirability-Based Multi-objective Optimization and Analysis of WEDM Characteristics of Aluminium (6082)/Tungsten Carbide Composites. Arab. J. Sci. Eng. 2019, 44, 893-909. [CrossRef]

22. Chockalingam, K.; Jawahar, N.; Muralidharan, N.; Jeyaraj, K. Material subtraction study of AISI T-15-HSS by wire cut electrical discharge machining (CNC-wire cut EDM) based on Taguchi grey relational analysis. Int. J. Mach. Mach. Mater. 2019, 21, 139-168.

23. Sathish, T.; Sabarirajan, N. Synthesis and optimization of AA7155-Zirconiam Carbide(ZrC) Composites Machining Parameters. J. New Mater. Electrochem. Syst. 2021, 1, 34-37. [CrossRef]

24. Anand Babu, K.; Venkataramaiah, P. Multi-response optimization in wire electrical discharge machining (WEDM) of Al6061/SiCp composite using hybrid approach. J. Manuf. Sci. Prod. 2015, 15, 327-338. [CrossRef]

25. Trujillo-Vazquez, E.; Pech-Canul, M.I.; Guia-Tello, J.C.; Pech-Canul, M.A. Surface chemistry modification for elimination of hydrophilic $\mathrm{Al}_{4} \mathrm{C}_{3}$ in $\mathrm{B}_{4} \mathrm{C} / \mathrm{Al}$ composites. Mater. Des. 2016, 89, 94-101. [CrossRef]

26. Ortega-Celaya, F.; Pech-Canul, M.; López-Cuevas, J.; Rendón-Angeles, J.C.; Pech-Canul, M.; Pech-Canul, M. Microstructure and impact behavior of $\mathrm{Al} / \mathrm{SiCp}$ composites fabricated by pressureless infiltration with different types of SiCp. J. Mater. Process. Technol. 2007, 183, 368-373. [CrossRef]

27. Hourmand, M.; Farahany, S.; Sarhan, A.A.D.; Noordin, M.Y. Investigating the electrical discharge machining (EDM) parameter effects on Al-Mg2Si metal matrix composite (MMC) for high material removal rate (MRR) and less EWR-RSM approach. Int. J. Adv. Manuf. Technol. 2015, 77, 831-838. [CrossRef]

28. Kavimani, V.; Prakash, K.S.; Thankachan, T. Influence of machining parameters on wire electrical discharge machining performance of reduced graphene oxide/magnesium composite and its surface integrity characteristics. Compos. Part B Eng. 2019, 167, 621-630. [CrossRef]

29. Mindivan, H.; Efe, A.; Kosatepe, A.H.; Kayali, E. Fabrication and characterization of carbon nanotube reinforced magnesium matrix composites. Appl. Surf. Sci. 2014, 318, 234-243. [CrossRef]

30. Boostani, A.F.; Tahamtan, S.; Jiang, Z.; Wei, D.; Yazdani, S.; Khosroshahi, R.A.; Mousavian, R.T.; Xu, J.; Zhang, X.; Gong, D. Enhanced tensile properties of aluminium matrix composites reinforced with graphene encapsulated SiC nanoparticles. Compos. Part A Appl. Sci. Manuf. 2015, 68, 155-163. [CrossRef]

31. Soni, H.; Narendranath, S.; Ramesh, M.R. Effects of wire electro-discharge machining process parameters on the machined surface of Ti $50 \mathrm{Ni} 49$ co 1 shape memory alloy. Silicon 2019, 11, 733-739. [CrossRef]

32. KKumar, S.S.; Uthayakumar, M.; Kumaran, S.T.; Parameswaran, P.; Mohandas, E.; Kempulraj, G.; Babu, B.R.; Natarajan, S. Parametric optimization of wire electrical discharge machining on aluminium based composites through grey relational analysis. J. Manuf. Process. 2015, 20, 33-39. [CrossRef]

33. Sachin Ashok, S.; Kulkarni, M.L. Optimization of machining parameters of WEDM for Nimonic-75 alloy using principal component analysis integrated with Taguchi method. J. King Saud. Univ. Sci. 2018, 30, 250-258.

34. Shorowordi, K.; Laoui, T.; Haseeb, A.; Celis, J.; Froyen, L. Microstructure and interface characteristics of $\mathrm{B}_{4} \mathrm{C}, \mathrm{SiC}_{\text {and }} \mathrm{Al}_{2} \mathrm{O}_{3}$ reinforced Al matrix composites: A comparative study. J. Mater. Process. Technol. 2003, 142, 738-743. [CrossRef]

35. Ghoreishi, R.; Roohi, A.H.; Ghadikolaei, A.D. Analysis of the influence of cutting parameters on surface roughness and cutting forces in high speed face milling of Al/SiC MMC. Mater. Res. Express 2018, 5, 086521. [CrossRef]

36. Sivaprakasam, P.; Hariharan, P.; Gowri, S. Optimization of Micro-WEDM Process of Aluminum Matrix Composite (A413-B 4 C): A Response Surface Approach. Mater. Manuf. Process. 2013, 28, 1340-1347. [CrossRef]

37. Mahanta, S.; Chandrasekaran, M.; Samanta, S.; Arunachalam, R. EDM investigation of Al 7075 alloy reinforced with $\mathrm{B}_{4} \mathrm{C}$ and fly ash nanoparticles and parametric optimization for sustainable production. J. Braz. Soc. Mech. Sci. Eng. 2018, 40, 263. [CrossRef]

38. Vijayabhaskar, S.; Rajmohan, T. Experimental Investigation and Optimization of Machining Parameters in WEDM of Nano-SiC Particles Reinforced Magnesium Matrix Composites. Silicon 2019, 11, 1701-1716. [CrossRef]

39. Bobbili, R.; Madhu, V.; Gogia, A.K. Effect of Wire-EDM Machining Parameters on Surface Roughness and Material Removal Rate of High Strength Armor Steel. Mater. Manuf. Process. 2013, 28, 364-368. [CrossRef] 
40. Miller, S.F.; Shih, A.J.; Qu, J. Investigation of the spark cycle on material removal rate in wire electrical discharge machining of advanced materials. Int. J. Mach. Tools Manuf. 2004, 44, 391-400. [CrossRef]

41. Habib, S. Optimization of machining parameters and wire vibration in wire electrical discharge machining process. Mech. Adv. Mater. Mod. Process. 2017, 3, 3. [CrossRef]

42. Hilšer, O.; Rusz, S.; Szkandera, P.; Čížek, L.; Kraus, M.; Džugan, J.; Maziarz, W. Study of the Microstructure, Tensile Properties and Hardness of AZ61 Magnesium Alloy Subjected to Severe Plastic Deformation. Metals 2018, 8, 776. [CrossRef]

43. Nagaraja, S.; Nagegowda, K.U.; Kumar, V.A.; Alamri, S.; Afzal, A.; Thakur, D.; Kaladgi, A.R.; Panchal, S.; Saleel, C.A. Influence of the Fly Ash Material Inoculants on the Tensile and Impact Characteristics of the Aluminum AA 5083/7.5SiC Composites. Materials 2021, 14, 2452. [CrossRef]

44. Akhtar, M.; Khan, M.; Khan, S.; Afzal, A.; Subbiah, R.; Ahmad, S.; Husain, M.; Butt, M.; Othman, A.; Bakar, E. Determination of Non-Recrystallization Temperature for Niobium Microalloyed Steel. Materials 2021, 14, 2639. [CrossRef]

45. Sathish, T.; Kaladgi, A.; Mohanavel, V.; Arul, K.; Afzal, A.; Aabid, A.; Baig, M.; Saleh, B. Experimental Investigation of the Friction Stir Weldability of AA8006 with Zirconia Particle Reinforcement and Optimized Process Parameters. Materials 2021, 14, 2782. [CrossRef]

46. Sharath, B.; Venkatesh, C.; Afzal, A.; Aslfattahi, N.; Aabid, A.; Baig, M.; Saleh, B. Multi Ceramic Particles Inclusion in the Aluminium Matrix and Wear Characterization through Experimental and Response Surface-Artificial Neural Networks. Materials 2021, 14, 2895. [CrossRef]

47. Chaluvaraju, B.V.; Afzal, A.; Vinnik, D.A.; Kaladgi, A.R.; Alamri, S.; Tirth, V. Mechanical and Corrosion Studies of Friction Stir Welded Nano Al2O3 Reinforced Al-Mg Matrix Composites: RSM-ANN Modelling Approach. Symmetry 2021, 13, 537. [CrossRef] 